\title{
Detection of Colletotrichum acutatum Sensu Lato on Strawberry by Loop-Mediated Isothermal Amplification
}

\author{
X. Zhang, T. C. Harrington, and J. C. Batzer, Department of Plant Pathology and Microbiology, Iowa State University, Ames, IA; \\ R. Kubota, Department of Molecular Biosciences and Bioengineering, University of Hawaii, Honolulu, HI; N. A. Peres, Department of Plant \\ Pathology, Gulf Coast Research and Education Center, University of Florida, Wimauma, FL; and M. L. Gleason, Department of Plant Pathol-
} ogy and Microbiology, Iowa State University

\begin{abstract}
Zhang, X., Harrington, T. C., Batzer, J. C., Kubota, R., Peres, N. A., and Gleason, M. L. 2016. Detection of Colletotrichum acutatum sensu lato on strawberry by loop-mediated isothermal amplification. Plant Dis. 100:1804-1812.

Colletotrichum acutatum, one of the most economically damaging pathogens of strawberry, is the primary causal agent of anthracnose fruit rot (AFR). A key challenge in managing AFR is detecting the pathogen on asymptomatic plants. To meet this need, a loop-mediated isothermal amplification (LAMP) assay was developed that incorporated two sets of primers: LITSG1, targeted on the intergenic transcribed spacer (ITS) region of ribosomal DNA, and Ltub2, on the $\beta$-tubulin 2 gene. In pure culture assays, Ltub2 was specific for detection of $C$. acutatum, whereas LITSG1 detected $C$. acutatum and two additional anthracnose pathogens, C. gloeosporioides and $C$. fragariae. LITSG1 had 10-fold lower detection threshold (20 pg of mycelial DNA) than Ltub2 (200 pg mycelial DNA) in detection of $C$. acutatum from pure culture. For detection on asymptomatic leaves, two protocols for dislodging C. acutatum for DNA extraction were compared: i) the sonicate-agitate (SA) method and ii) the freezeincubate-sonicate-agitate (FISA) method, which initially freezes tissues, followed by 2 days of incubation at $26^{\circ} \mathrm{C}$ in darkness, and then, sonication and agitation. Both methods were used for greenhouse-grown plant leaves that

had been spray inoculated with serial dilutions ranging from $1.5 \times 10^{6}$ to 1.5 conidia $\mathrm{ml}^{-1}$. The FISA method produced more repeatable results than the SA method. For the FISA method, detection limits (expressed as initial inoculum concentrations) using LITSG1 and Ltub2 were $1.5 \times 10^{1}$ and $1.5 \times 10^{2}$ conidia $\mathrm{ml}^{-1}$, respectively. For composite samples comprised of inoculated $\left(1.5 \times 10^{6}\right.$ conidia $\left.\mathrm{ml}^{-1}\right)$ and noninoculated leaves of greenhouse-grown strawberry, the two sets of LAMP primers were compared using the SA method. Primer set LITSG1 consistently detected the pathogen from a single inoculated leaf in bulk samples of 50 or fewer pathogen-free leaves, whereas Ltub2 consistently detected one inoculated leaf in 20 or fewer pathogen-free leaves. Using primer set LITSG1, FISA was more sensitive than SA for detecting $C$. acutatum on leaves of fieldgrown plants from Florida. In an Iowa field trial using the FISA method, both primer sets detected $C$. acutatum in samples of asymptomatic leaves 6 days before fruit symptoms appeared. The results indicate that the LAMP assay has potential to provide a simplified method for detection of $C$. acutatum on asymptomatic strawberry plants.
\end{abstract}

Colletotrichum species cause anthracnose of strawberry as well as other diseases on a wide range of hosts (Cannon et al. 2012). Three pathogens, Colletotrichum acutatum J.H. Simmonds, $C$. gloeosporioides (Penz.) Penz. \& Sacc., and C. fragariae A.N. Brooks, cause sunken, brown necrotic lesions on several strawberry tissues (Howard et al. 1992; Smith 2008; Xie et al. 2010). Of the three pathogens, C. acutatum is the most prevalent, causing severe outbreaks of anthracnose fruit rot (AFR) as well as lesions on petioles, flowers, and roots of strawberry (Howard et al. 1992; Peres et al. 2005). In the absence of symptoms, C. acutatum can produce secondary conidia on leaf surfaces, which may ultimately serve as a source of primary infections on fruit (Freeman et al. 2001b; Leandro et al. 2001). After colonization of host vegetative tissues in plant nurseries or production fields, the pathogen remains quiescent for weeks to months, until the onset of fruit rot epidemics (Leandro 2002). Disease management is challenging when symptoms appear and weather conditions favor disease development and production of conidia on fruit lesions (Pavan et al. 2011). Long-distance spread is mostly through transplants (Peres et al. 2005). Therefore, reliable and convenient detection of $C$. acutatum is needed before symptoms are observed.

The taxonomic status of $C$. acutatum is in flux. Freeman et al. (2001a) used internal transcribed spacer (ITS) 2 sequences of ribosomal DNA to place $C$. acutatum into four subgroups. Guerber et al. (2003) used

Corresponding author: M. L. Gleason; Email: mgleason@iastate.edu

Accepted for publication 1 April 2016.

http://dx.doi.org/10.1094/PDIS-09-15-1013-RE

(C) 2016 The American Phytopathological Society phylogenetic analysis and restriction fragment length polymorphism (RFLP) of several gene introns to delineate seven clades in C. acutatum. Subsequently, eight worldwide subgroups were distinguished, based on 5.8S-ITS sequence information, which displayed a certain degree of correlation with host origin and geographical distribution (Sreenivasaprasad and Talhinhas 2005). Within geographic regions, C. acutatum from strawberry was divided into two or more subgroups based on 5.8S-ITS sequences (Denoyes-Rothan et al. 2003; Martinez-Culebras et al. 2003; Van Hemelrijck et al. 2010). In Florida, C. acutatum isolates also showed some degree of host specialization and were highly pathogenic on their original hosts (MacKenzie et al. 2009). A recent study split the original $C$. acutatum complex into 30 species (Damm et al. 2012). For the present paper, however, we will consider these new taxa as $C$. acutatum sensu lato, pending publication of additional research on their biology and ecology.

Several molecular detection methods for $C$. acutatum sensu lato have been developed (Debode et al. 2009; Martinez-Culebras et al. 2003; Pérez-Hernández et al. 2008; Sreenivasaprasad et al. 1996). Although polymerase chain reaction (PCR) is a valuable tool to investigate the etiology of the disease (Parikka and Lemmetty 2004), significant equipment cost and technical training requirements preclude its use for routine screening of plant tissues outside of laboratory settings. Real-time PCR provides dependable detection (Debode et al. 2009), but its use by the strawberry industry is limited because the instruments are even more expensive than for conventional PCR and the methods are relatively complex.

Compared with existing molecular methods, loop-mediated isothermal amplification (LAMP) has proven to be relatively simple to conduct, cost-effective, sensitive, and specific for several other plant pathogens, including Fusarium graminearum, Botrytis cinerea, Phytophthora ramorum, and Ralstonia solanacearum (Kubota et al. 
2008; Niessen and Vogel 2010; Tomlinson et al. 2007; Tomlinson et al. 2010a, and b). The method uses six primers in total: two outer primers, F3 and B3, and two internal primers, FIP and BIP. FIP is composed of sequence $\mathrm{F} 2$ and the complementary sequence to F1, whereas BIP is composed of the sequence B2 plus the complementary sequence to $\mathrm{B} 1$. These four primers recognize six regions on the target DNA and two loop primers located at the loop region of the target DNA that can accelerate the amplification (Nagamine et al. 2002; Notomi et al. 2000). Target DNA amplification can be detected visually by means of turbidity resulting from the amplification byproduct magnesium pyrophosphate or fluorescent dye binding to double-stranded DNA (Mori et al. 2001; Tomita et al. 2008; Tomlinson et al. 2007).

The objective of this research was to develop a LAMP assay for detecting the strawberry pathogen $C$. acutatum in greenhouse- and field-grown plants to provide a more reliable, convenient, and costeffective diagnostic tool for the strawberry industry.

\section{Materials and Methods}

Pathogen isolates and culture. Thirty-seven C. acutatum isolates from strawberry, 46 isolates of $C$. acutatum from other hosts, and six isolates of other fungi isolated from strawberry that had sequence information were listed in Table 1. Five isolates that were identified by their morphological characters as Botrytis cinerea, Gnomonia sp., Phomopsis sp., Cladosporium sp., and Penicillium sp. were also used in this research. All the isolates were used for LAMP testing and were maintained in $15 \%$ glycerol at $-80^{\circ} \mathrm{C}$. Prior to assays, isolates were transferred to potato dextrose agar (PDA) and were incubated for 5 to 10 days at $26^{\circ} \mathrm{C}$ in darkness.

DNA extraction from pure cultures. Genomic DNA samples used for evaluating primer specificity were prepared from approximately $0.5 \mathrm{~g}$ of mycelium suspended in $40 \mu \mathrm{l}$ of PrepMan Ultra sample preparation reagent (Life Technologies, Carlsbad, CA). The mixture was incubated at $56^{\circ} \mathrm{C}$ for $30 \mathrm{~min}$ and, then, at $100^{\circ} \mathrm{C}$ for $10 \mathrm{~min}$, in a thermocycler (MJ Research PTC-100TM; GMI, Inc., Ramsey, MS), and was centrifuged at 13,000 rpm for 1 min. Suspensions were either used immediately as LAMP templates or stored at $-20^{\circ} \mathrm{C}$ for later use.

LAMP primer design. The nuclear rDNA operon spanning the ITS1, 5.8S ribosomal RNA gene, ITS2 for GenBank sequence EU647302 (MacKenzie et al. 2009) and the $\beta$-tubulin 2 gene GenBank sequence AJ409296 (Damm et al. 2012; Debode et al. 2009), which had been used successfully as target genes for other $C$. acutatum detection methods, were selected for LAMP primer set design. The software LAMP Designer (Premier Biosoft, Palo Alto, CA) identified potential LAMP primer positions and calculated melting temperature, $\mathrm{GC} \%$, and hairpin structures for primer sets. Eight primer sets for the 495-bp fragment of the 5.8S and ITS2 region and two primer sets for the 550-bp $\beta$-tubulin 2 gene were generated by LAMP Designer. After testing with DNA extracted from mycelium of strain 07.7, the most stable and sensitive primer sets for LITSG1 and Ltub2 were selected.

DNA amplification. LAMP reactions were performed using primer sets selected from the primer design software (Table 2). Each reaction contained $1 \mu \mathrm{l}$ of DNA extract and $24 \mu \mathrm{l}$ of master mix; the reaction mixture contained $0.32 \mathrm{U}$ of Bst DNA polymerase per microliter (New England Biolabs, Ipswich, MA), $1 \mu$ l of ThermoPol buffer, $1.4 \mathrm{mM}$ each dNTP, $8 \mathrm{mM} \mathrm{MgSO}_{4}$ (including $2 \mathrm{mM}$ in Thermopol buffer), $1 \mathrm{M}$ betaine, $0.2 \mu \mathrm{M}$ of each external primer (F3 and B3), $1.6 \mu \mathrm{M}$ of each internal primer (FIP and BIP), and $0.8 \mu \mathrm{M}$ of each loop primer (LoopF and LoopB). Strain 07.7 of C. acutatum, isolated from strawberry fruit in Florida (Table 1), was used as a positive control and sterile distilled water (SDW) was used as a negative control. After reactions were incubated at $63^{\circ} \mathrm{C}$ for $50 \mathrm{~min}$ in a water bath, amplified products were visualized either by gel electrophoresis or by adding $2 \mu \mathrm{l}$ of PicoGreen double-stranded DNA reagent (Invitrogen, Carlsbad, CA); in the latter case, fluorescence was observed under UV light. To prevent contamination, LAMP reactions and product detection were performed in different rooms using different laminar flow hoods and pipettes.
A PCR method using primer pair CaInt2 and ITS4 (Sreenivasaprasad et al. 1996) was used in in vitro and in vivo sensitivity tests as a comparison with LAMP. PCR was performed in a total volume of $25 \mu \mathrm{l}$ containing $1 \mu \mathrm{l}$ of DNA as template, $0.5 \mu \mathrm{M}$ of each primer, $0.2 \mathrm{mM}$ dNTPs, $5 \mu \mathrm{l} 5 \times$ Green GoTaq reaction buffer, $0.4 \mathrm{mM} \mathrm{MgCl}_{2}, 2 \%$ dimethylsulfoxide (DMSO) (Sigma-Aldrich, St. Louis), and $1.25 \mathrm{U}$ of GoTaq Flexi DNA polymerase (Promega Corp., Madison, WI). PCR amplification was performed in a thermocycler (MJ Research PTC-100TM), using the following program: $95^{\circ} \mathrm{C}$ for $90 \mathrm{~s}$, followed by 35 cycles of $95^{\circ} \mathrm{C}$ for $35 \mathrm{~s}, 55^{\circ} \mathrm{C}$ for $1 \mathrm{~min}, 72^{\circ} \mathrm{C}$ for $1 \mathrm{~min}$, and a final elongation at $72^{\circ} \mathrm{C}$ for $1 \mathrm{~min}$.

Primer set ITS1F/ITS4 (Gardes and Bruns 1993; White et al. 1990) was used for sequencing the 5.8S-ITS region. Then, the sequences were compared with the published type strains' sequences to get the ITS barcode names (Table 1). Primer set TB5/TB6 (Talhinhas et al. 2002) was used for sequencing the $\beta$-tubulin 2 gene and finding the difference between LAMP-positive versus LAMP-negative C. acutatum strains. PCR for DNA sequencing was performed in a total volume of $30 \mu \mathrm{l}$, containing $1 \mu \mathrm{l}$ of DNA as template, $0.5 \mu \mathrm{M}$ of each primer, $0.2 \mathrm{mM}$ dNTPs, $7 \mu \mathrm{l}$ of $5 \times$ Green GoTaq reaction buffer, $0.4 \mathrm{mM} \mathrm{MgCl}, 2 \%$ DMSO (Sigma-Aldrich), and $1.25 \mathrm{U}$ of GoTaq Flexi DNA polymerase (Promega Corp.). PCR amplifications were performed in a thermocycler (MJ Research PTC100TM). Amplification conditions for the 5.8S-ITS region were: $95^{\circ} \mathrm{C}$ for $90 \mathrm{~s}$, followed by 35 cycles of $95^{\circ} \mathrm{C}$ for $35 \mathrm{~s}, 57^{\circ} \mathrm{C}$ for $1 \mathrm{~min}, 72^{\circ} \mathrm{C}$ for $1 \mathrm{~min}$, and a final elongation at $72^{\circ} \mathrm{C}$ for $1 \mathrm{~min}$; for $\beta$-tubulin 2 : $95^{\circ} \mathrm{C}$ for $90 \mathrm{~s}$, followed by 35 cycles of $95^{\circ} \mathrm{C}$ for $35 \mathrm{~s}, 65^{\circ} \mathrm{C}$ for $1 \mathrm{~min}, 72^{\circ} \mathrm{C}$ for $1 \mathrm{~min}$, and a final elongation at $72^{\circ} \mathrm{C}$ for $1 \mathrm{~min}$. The PCR product was purified with a QIAquick DNA purification kit (Qiagen, Valencia, CA) and automated sequencing was performed with a DNA analyzer (Model 3730xl; Applied Biosystems, Foster City, CA) at the Iowa State University DNA Sequencing and Synthesis Facility (Ames, IA).

In vitro specificity and sensitivity tests. Thirty-seven strawberry C. acutatum isolates, 46 C. acutatum isolates from other hosts, and 11 other fungi from strawberry were used in this research for the in vitro specificity test. Genomic DNA extraction and a LAMP assay with these samples were performed as described previously; the LAMP assay was conducted at least three times for each isolate, in order to obtain consistent results.

C. acutatum 07.7 isolated from strawberry fruit, which is from the most dominant strawberry pathogen species, $C$. nymphaeae, of the species complex (Damm et al. 2012), was used for evaluating LAMP primer sensitivity. DNA extracted from mycelium was adjusted to $20 \mathrm{ng} \mu \mathrm{l}^{-1}$, using a spectrophotometer (Model ND-1000; NanoDrop Technologies, Inc., Wilmington, DE), and then, six 10-fold serial dilutions, ranging from $20 \mathrm{ng}$ to $0.2 \mathrm{pg}$ per microliter, were made with SDW. SDW also served as a negative control. LAMP assays were then performed as previously described. As a comparison, serial dilutions were also amplified with PCR primers CaInt2 and ITS4 (Sreenivasaprasad et al. 1996). The LAMP assay was conducted three times in order to obtain consistent results.

Detection threshold on strawberry leaves. At Iowa State University, day-neutral strawberry ('Tristar') crowns were planted in 15-cm-diameter plastic pots containing a 1:2:1 mixture of peat, perlite, and soil and were maintained in a greenhouse at $25 \pm 10^{\circ} \mathrm{C}$ with a 16-h photoperiod. Plants were fertilized weekly with a $5 \%$ solution of 21-5-20 (N-P-K) (400 ppm N; Miracle Gro Excel, The Scotts Company, Marysville, $\mathrm{OH})$, and flowers were removed twice weekly to promote development of leaves. Conidia suspensions of strain 03.32 (from the $C$. nymphaeae group of $C$. acutatum sensu lato) were prepared from 10-day-old cultures on PDA plates. Plates were flooded with SDW and colonies were scraped with sterile swabs to dislodge conidia. Suspensions were filtered through two layers of cheesecloth and were then adjusted with SDW to the needed concentration, using a hemacytometer. Ten-fold dilutions, ranging from $1.5 \times 10^{6}$ to 1.5 conidia per milliliter, were used as inoculum to determine LAMP detection thresholds on greenhouse-grown strawberry leaves. A total of 48 fully expanded trifoliate leaves were excised at the petiole base and were brought to the laboratory. Six 
leaves were placed adaxial side up on wire mesh and were then sprayed with SDW, using an electronic atomizer (Series 571 air compressor; DeVilbiss Inc., Somerset, KY). Successive six-leaf samples were then spray-inoculated with increasing concentrations of conidia, beginning with 1.5 conidia $\mathrm{ml}^{-1}$. Inoculated leaves supported on wire mesh were transferred to $24 \times 34 \times 6$-cm crispers and were placed above $500 \mathrm{ml}$ of SDW. The cut ends of the petioles were inserted through the mesh into the water to minimize desiccation (Leandro et al. 2001). The boxes were then sealed with plastic tape to maintain high relative humidity and were incubated in darkness for 2 days at $25^{\circ} \mathrm{C}$.

Each six-leaf sample was divided into two three-leaf groups to compare protocols for dislodging C. acutatum before DNA extraction: the sonicate-agitate (SA) method and the freeze-incubate-sonicate-agitate (FISA) method (Pérez-Hernández et al. 2008). For each group, three leaves were used as a single replicate. Leaves from the SA subsets were removed from the crispers, were air-dried at room temperature for $30 \mathrm{~min}$, and were then placed in $50 \mathrm{ml}$ of $0.05 \%$ polyoxyethylene sorbitan monolaurate (Tween 20) in 100-ml polyethylene bags. The bags were sonicated for $30 \mathrm{~min}$ in an ultrasonic cleaner (Model B-2200R-1; Branson Cleaning Equipment Company, Shelton, CT) and were agitated manually for $1 \mathrm{~min}$. Leaves in the FISA subsets were removed from crispers, were air dried at room temperature for $30 \mathrm{~min}$, were frozen at $-20^{\circ} \mathrm{C}$ for $3 \mathrm{~h}$, and were incubated at $25^{\circ} \mathrm{C}$ in darkness for 2 days. Each leaf was immersed in $50 \mathrm{ml}$ of $0.05 \%$ Tween 20 in a sealed sample bag, was sonicated for $30 \mathrm{~min}$, and was manually agitated in the plastic bag for $1 \mathrm{~min}$. Suspensions from SA and FISA methods were then transferred to sterile $50-\mathrm{ml}$ plastic tubes and were centrifuged for $10 \mathrm{~min}$ at 4,000 rpm; supernatants were discarded and pellets were resuspended in $1.5 \mathrm{ml}$ of SDW, were transferred to 1.5-ml Eppendorf tubes, and were centrifuged for $15 \mathrm{~min}$ at 13,000 rpm. The pellets served as templates for total DNA extraction, using $40 \mu \mathrm{l}$ of PrepMan Ultra sample preparation reagent as described previously.

Detection on inoculated leaves in bulked samples. To determine sensitivity of the LAMP assay in bulked samples of leaves, 21 fully expanded strawberry trifoliate leaves from the greenhouse-grown plants were collected, were spray-inoculated with $1.5 \times 10^{6}$ conidia per milliliter of strain 03.32, as described previously, and were incubated in crispers for 2 days. Leaves were then removed from the crispers and were air-dried at room temperature $\left(18\right.$ to $\left.25^{\circ} \mathrm{C}\right)$ for about $30 \mathrm{~min}$. Approximately 500 fully expanded, noninoculated strawberry leaves were also collected. Next, a single inoculated trifoliate leaf was combined with either $1,10,20,30,40$, or 50 noninoculated trifoliate leaves in a plastic bag with 50,100, 200,300, 400, or

Table 1. Colletotrichum species and other fungal isolates from different hosts and states ${ }^{\mathrm{a}}$

\begin{tabular}{|c|c|c|c|c|c|c|}
\hline \multirow[b]{2}{*}{ Species/host } & \multirow[b]{2}{*}{ ITS barcode } & \multirow[b]{2}{*}{$\beta$-tubulin 2 barcode } & \multirow[b]{2}{*}{ Isolate code } & \multirow[b]{2}{*}{ Origin $^{\mathbf{b}}$} & \multicolumn{2}{|c|}{ LAMPc } \\
\hline & & & & & LITSG1 & Ltub2 \\
\hline \multicolumn{7}{|l|}{ C. acutatum } \\
\hline \multirow[t]{4}{*}{$\begin{array}{l}\text { Fragaria } \times \text { ananassa } \\
\quad \text { (strawberry) }\end{array}$} & $\begin{array}{l}\text { C. guajavae (NR_111738) } \\
\text { and C. paxtonii } \\
\text { (NR_111742) 540/540 }\end{array}$ & $\begin{array}{l}\text { C. nymphaeae } \\
\text { (JQ949848) 412/412 }\end{array}$ & $\begin{array}{l}\text { Cal-A, Goff, Mil-1, Mil-2, } \\
\text { MS1ChanPop\#1, OKU\#1, } \\
07.7,03.32\end{array}$ & $\begin{array}{l}\text { CA, MO, MS, } \\
\text { OK }\end{array}$ & + & + \\
\hline & $\begin{array}{l}\text { C. guajavae (NR_111738) } \\
\text { and C. paxtonii } \\
\text { (NR_111742) 540/540 }\end{array}$ & NT & $\begin{array}{l}\text { CA-1, NC1, NC2, NC3, NC4, } \\
\text { NC5, NC6, NC7, NC8, } \\
02.179,12.314\end{array}$ & $\mathrm{NC}, \mathrm{FL}$ & + & + \\
\hline & $\begin{array}{l}\text { C. fioriniae (NR111747) } \\
540 / 540\end{array}$ & $\begin{array}{l}\text { C. fioriniae (JQ949943) } \\
413 / 413\end{array}$ & $\begin{array}{l}\text { CF167, Cooley1, Cooley2, } \\
01.93\end{array}$ & FL, MA, MI & + & + \\
\hline & NT & NT & $\begin{array}{l}07.14,08.27,10.9,10.10 \\
\text { 10.105, } 11.342,05.226 \\
09.109,11.101, \mathrm{NC} 10 \\
\mathrm{NC} 13, \mathrm{NC} 15, \mathrm{NC} 19, \mathrm{NC} 21\end{array}$ & FL, NC & + & + \\
\hline Prunus persica (peach) & $\begin{array}{l}\text { C. fioriniae (NR111747) } \\
540 / 540\end{array}$ & $\begin{array}{l}\text { C. fioriniae (JQ949943) } \\
413 / 413\end{array}$ & Ca.Sc.PH8.04, Ca.Sc.PH9.04 & $\mathrm{SC}$ & + & + \\
\hline $\begin{array}{l}\text { Vaccinium corymbosum } \\
\text { (blueberry) }\end{array}$ & $\begin{array}{l}\text { C. fioriniae (NR111747) } \\
540 / 540\end{array}$ & $\begin{array}{l}\text { C. fioriniae (JQ949943) } \\
413 / 413\end{array}$ & 04.81 & $\mathrm{CA}$ & + & + \\
\hline Pyrus sp. (pear) & $\begin{array}{l}\text { C. fioriniae (NR111747) } \\
540 / 540\end{array}$ & $\begin{array}{l}\text { C. fioriniae (JQ949943) } \\
412 / 413\end{array}$ & PearFlow & MS & + & + \\
\hline $\begin{array}{l}\text { Solanum lycopersicum } \\
\text { (tomato) }\end{array}$ & $\begin{array}{l}\text { C. fioriniae (NR111747) } \\
540 / 540\end{array}$ & $\begin{array}{l}\text { C. fioriniae (JQ949943) } \\
\quad 412 / 413\end{array}$ & BJSTom, TBPop & MS & + & + \\
\hline \multirow[t]{2}{*}{$\begin{array}{l}\text { Rubus idaeus } \\
\text { (raspberry) }\end{array}$} & $\begin{array}{l}\text { C. fioriniae (NR111747) } \\
540 / 540\end{array}$ & $\begin{array}{l}\text { C. fioriniae (JQ949943) } \\
\quad 411 / 413\end{array}$ & RBPop & MS & + & + \\
\hline & NT & NT & $\begin{array}{l}\text { 04.80, 05.88, 05.218, 05.219, } \\
\text { 05.195, 05.197, 04.52, } \\
04.53,05.148\end{array}$ & $\begin{array}{l}\text { CA, FL, GA, } \\
\text { MI, MS }\end{array}$ & + & + \\
\hline \multirow[t]{4}{*}{$\begin{array}{l}\text { Citrus aurantifolia } \\
\text { (Key lime) }\end{array}$} & $\begin{array}{l}\text { C. costaricense } \\
\text { (NR111731) and C. } \\
\text { limitticola } \\
\text { (NR_111733) } 540 / 540\end{array}$ & $\begin{array}{l}\text { C. limetticola (JQ949844) } \\
\quad 412 / 412\end{array}$ & $\begin{array}{l}\text { MLK1, MLK4, MLK7, } \\
\text { KLA12.475, KLA3, }\end{array}$ & FL & + & + \\
\hline & $\begin{array}{l}\text { C. costaricense } \\
\text { (NR111731) and } C \text {. } \\
\text { limitticola } \\
(\mathrm{NR} 111733) 540 / 540\end{array}$ & NT & $\begin{array}{l}\text { Hm-1, FL.KLA.1, FL.KLA.5, } \\
\text { FL.KLA.7, FL.KLA. } 8\end{array}$ & FL & + & + \\
\hline & $\begin{array}{l}\text { C. scovillei (NR_111737) } \\
539 / 540\end{array}$ & $\begin{array}{l}\text { C. costaricense } \\
\text { (JQ949831) 409/412 }\end{array}$ & KLA4.37 & FL & + & \pm \\
\hline & & & & $($ cont & nued on ne. & tt page) \\
\hline \multicolumn{7}{|c|}{$\begin{array}{l}\text { Listed by common species name, host, "modern species" according to intergenic transcribed spacer (ITS) and } \beta \text {-tubulin } 2 \text { barcodes (Damm et al. 2012), isolate } \\
\text { code, state of origin, and reaction results in loop-mediated isothermal amplification (LAMP) assays with two sets of primers (LITSG1 and Ltube 2). Colletotrichum } \\
\text { isolates and modern species names are based on comparison of the 5.8S-ITS region and } \beta \text {-tubulin } 2 \text { sequence of the type strains (Damm et al. 2012), followed by } \\
\text { GenBank number and the identical base pair/compared base pair ratio. NT = not tested. }\end{array}$} \\
\hline \multicolumn{7}{|c|}{ 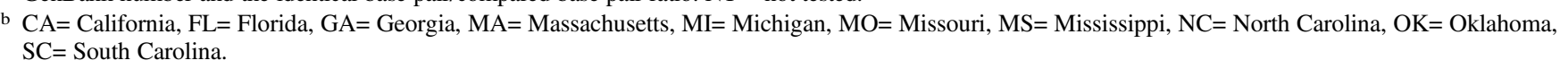 } \\
\hline
\end{tabular}


$500 \mathrm{ml}$, respectively, of SDW containing $0.05 \%$ Tween 20. Each combination was replicated three times. The sample bags were sonicated for $30 \mathrm{~min}$ and were manually agitated for $1 \mathrm{~min}$ (SA method). From each sample, $50 \mathrm{ml}$ of the extraction suspension was transferred to $50-\mathrm{ml}$ plastic tubes and was centrifuged for $10 \mathrm{~min}$ at 4,000 rpm; $1.5 \mathrm{ml}$ of the precipitate, including the pellet, was transferred to an Eppendorf tube and was centrifuged for $15 \mathrm{~min}$ at 13,000 rpm. The pellet was then resuspended in SDW, was centrifuged again for $15 \mathrm{~min}$ at 13,000 rpm, and was used for total DNA extraction, as previously described. Composite leaf samples were analyzed using both LAMP and PCR.

Detection on field-grown strawberry plants. Assays of fieldgrown plants were done at climatically distinct locations in Iowa and Florida, using different cultivars to assess robustness of the LAMP method. At the Iowa State University Horticulture Research Station near Gilbert, Iowa, crowns of 'Tristar' were planted on May 18, 2013, in double rows $0.3 \mathrm{~m}$ apart on nine 27.4-m-long beds on white-on-black plastic mulch with $1.8-\mathrm{m}$ centers. On the evening of July 3, 2013, 15 liters of $C$. acutatum suspension $\left(1.5 \times 10^{6}\right.$ conidia $\mathrm{ml}^{-1}$ ) of a combination of strains $03.32,05.226,11.101$, and $\mathrm{NC} 2$, prepared as previously described, was sprayed to runoff on all plants in the plot, using a backpack sprayer. Two days after inoculation, one symptomless leaf per subplot and a total of 12 flowers were collected arbitrarily, and then, each sample was placed in a single plastic bag. Fifty-four samples (42 leaves and 12 flowers) were tested individually. C. acutatum was extracted using the FISA method, and DNA samples were prepared as previously described. As a comparison of sensitivity, extracted DNA samples were also analyzed by conventional PCR, using primers CaInt2 and ITS4.
In a commercial field near Wimauma, Florida, four cultivars were planted on October 11, 2013, namely, 'Florida Radiance' (resistant to C. acutatum), 'Sweet Charlie' (resistant), 'Strawberry Festival' (moderately resistant), and 'Camarosa' (highly susceptible). Most of these plants were either root-dip inoculated on the planting day or sprayinoculated on October 22, 2013, with suspensions of C. acutatum

Table 2. Primers used for development of a loop-mediated isothermal amplification assay for Colletotrichum acutatum sensu lato from strawberrya

\begin{tabular}{lc}
\hline Primer $^{\text {a }}$ & \multicolumn{1}{c}{ Sequence } \\
\hline LITSG1F3 & TAACAACGGATCTCTTGGTTC \\
LITSG1B3 & GAGACGTTAGTTACTACGCAA \\
LITSG1FIP (F1c+F2) $(\mathrm{F} 1 \mathrm{c}+\mathrm{F} 2)$ & TGCTCGCCAGAATGCTGGGCAGA \\
& ATTCAGTGAATCATCG \\
LITSG1BIP (B1c+B2) & TCGAGCGTCATTTCAACCCTCGT \\
& CCGCCACTACCTTTAAG \\
LITSG1LoopF & CGCAATGTGCGTTCAAAGA \\
LITSG1LoopB & AAGCACCGCTTGGTTTTG \\
Ltub2F3 & TAACCAGATTGGTGCTGC \\
Ltub2B3 & TTCGTCAATAGGATTGCCTG \\
Ltub2FIP (F1c+F2) & TGACATACACGCCATTGCTGTAT \\
& CTCGTACTGACCTTGGT \\
Ltub2BIP (B1c+B2) & GGACCCAGCAGCTAATCATACCT \\
& TGAAGTAGACGCTCATGC \\
Ltub2LoopF & GTGCTCGCCAGAGATGTT \\
Ltub2LoopB & ATAGGTACAACGGCACTTCC \\
\hline a Outer primers were F3 and B3, internal primers were FIP (F1c+F2) and BIP \\
(B1c+B2), and loop primers were LoopF and LoopB.
\end{tabular}

Table 1. (continued from preceding page)

\begin{tabular}{|c|c|c|c|c|c|c|}
\hline \multirow[b]{2}{*}{ Species/host } & \multirow[b]{2}{*}{ ITS barcode } & \multirow[b]{2}{*}{$\beta$-tubulin 2 barcode } & \multirow[b]{2}{*}{ Isolate code } & \multirow[b]{2}{*}{ Origin $^{b}$} & \multicolumn{2}{|c|}{ LAMPc $^{c}$} \\
\hline & & & & & LITSG1 & Ltub2 \\
\hline \multirow[t]{4}{*}{ Citrus sinensis (orange) } & $\begin{array}{l}\text { C. scovillei (NR_111737) } \\
539 / 540\end{array}$ & $\begin{array}{l}\text { C. costaricense } \\
\text { (JQ949831) 409/412 }\end{array}$ & $\begin{array}{l}\text { FL.PFD.14, FL.PFD.15, FL. } \\
\text { PFD.16, Arcadia, Coca cola }\end{array}$ & FL & + & \pm \\
\hline & $\begin{array}{l}\text { C. scovillei (NR_111737) } \\
539 / 540\end{array}$ & NT & STL.FTP.1s, RCO.IMK.4 & FL & + & \pm \\
\hline & $\begin{array}{l}\text { C. scovillei (NR_111737) } \\
539 / 540\end{array}$ & NT & MRN.IND.2s & FL & + & + \\
\hline & NT & NT & FL.PFD.7, FL.PFD.8 & FL & + & + \\
\hline \multirow[t]{2}{*}{$\begin{array}{l}\text { Rumohra adiantiformis } \\
\text { (leatherleaf fern) }\end{array}$} & $\begin{array}{l}\text { C. scovillei (NR_111737) } \\
540 / 540\end{array}$ & $\begin{array}{l}\text { C. tamarilli (JQ949835) } \\
\quad 411 / 412\end{array}$ & $05.115,05.205$ & FL & + & + \\
\hline & NT & NT & $\begin{array}{l}\text { 05.121, 05.129, 05.130, } \\
\text { 05.133, 05.141, 05.144, } \\
\text { 05.159 }\end{array}$ & FL & + & + \\
\hline \multicolumn{7}{|l|}{ C. gloeosporioides } \\
\hline \multirow[t]{3}{*}{$\begin{array}{l}\text { Fragaria } \times \text { ananassa } \\
\quad \text { (strawberry) }\end{array}$} & C. ti (NR120143) 494/494 & NT & $\begin{array}{l}95.68,97.48 \mathrm{~A}, 99.51,00.182 \\
\quad 00.181,00.117\end{array}$ & FL & + & - \\
\hline & $\begin{array}{l}\text { C. gloeosporioides } \\
\text { (HQ022353) 495/495 }\end{array}$ & NT & $96.14,96.15 \mathrm{~A}$ & FL & + & - \\
\hline & $\begin{array}{l}\text { C. aeschynomenes } \\
\text { (NR120133) 495/495 }\end{array}$ & NT & 07.78 & FL & + & - \\
\hline \multicolumn{7}{|l|}{ C. fragariae } \\
\hline \multirow[t]{3}{*}{$\begin{array}{l}\text { Fragaria } \times \text { ananassa } \\
\quad(\text { strawberry })\end{array}$} & $\begin{array}{l}\text { C. fragariae (KC790937) } \\
497 / 497\end{array}$ & NT & $95.21,03.30,95.29$ & FL, MS & + & - \\
\hline & $\begin{array}{l}\text { C. fragariae (HQ188923) } \\
498 / 498\end{array}$ & NT & $\begin{array}{l}00.176,01.184,07.76 \\
02.205,04.99,03.22 \\
02.181\end{array}$ & FL & + & - \\
\hline & $\begin{array}{l}\text { C. fragariae (HQ188923) } \\
497 / 498\end{array}$ & NT & $02.178,03.17$ & FL & + & - \\
\hline \multicolumn{7}{|l|}{ Epicoccum sorghi } \\
\hline $\begin{array}{l}\text { Fragaria } \times \text { ananassa } \\
\quad(\text { strawberry })\end{array}$ & FJ427067 440/440 & NT & EP2H5, EP1B1.2 & IA & - & - \\
\hline \multicolumn{7}{|l|}{ Phoma herbarum } \\
\hline $\begin{array}{l}\text { Fragaria } \times \text { ananassa } \\
\quad(\text { strawberry })\end{array}$ & KJ188712 450/450 & NT & EP1B45.1, EP1B45.2 & IA & - & - \\
\hline \multicolumn{7}{|l|}{ Phoma pomorum } \\
\hline $\begin{array}{l}\text { Fragaria } \times \text { ananassa } \\
\quad(\text { strawberry })\end{array}$ & FJ839845 458/458 & NT & EP2F34.1, EP2F34.2 & IA & - & - \\
\hline
\end{tabular}


ranging from $10^{3}$ to $10^{5}$ conidia per milliliter. Leaves were collected on January 22, 2014. Thirty leaves were selected arbitrarily from each cultivar, were placed in a plastic bag, and were shipped in an air-padded envelope at ambient temperature to Iowa State University. The samples arrived 2 days later, at which time the trifoliate leaf samples were selected arbitrarily for testing by either the SA or FISA method as well as the LITSG1 assay.

\section{Results}

Assay specificity. Both primer sets detected only Colletotrichum spp. among all the isolates that tested, but primer set Ltub2 did not detect some $C$. acutatum isolates from Key lime and orange (Table 1). The ITS primer set sequences (Table 2) aligned closely with the ITS region of eight distinct molecular groups within C. acutatum (Sreenivasaprasad and Talhinhas 2005) but showed differences at the target sites when aligned with $C$. gloeosporioides and C. fragariae (Fig. 1). However, isolates of $C$. gloeosporioides and $C$. fragariae were also amplified by LITSG1. Because of cross-reaction of the ITS primers with the latter two species, the $\beta$-tubulin 2 gene, which has more variation among species than ITS, was chosen as a candidate target gene, and the 550-bp fragment AJ409296 (C. nymphaeae) was used for primer design (Damm et al. 2012; Debode et al. 2009). The positions of the primers as well as sequence differences of both primer sets and the target genes are shown in Figures 1 and 2. The Ltub2 primer set exhibited more base-pair differences and gaps than LITSG1 at target sites with the sequences of $C$. gloeosporioides and $C$. fragariae, which allowed Ltub2 to detect $C$. acutatum specifically. In order to find out which new species the detected isolates belonged to, the 5.8S-ITS region and the $\beta$-tubulin 2 gene were sequenced, and the closest sequences with numbers of identical base pairs were listed (Table 1). Besides isolates from the genera Epicoccum and Phoma that were isolated from strawberry plants in Iowa, Botrytis cinerea, Gnomonia sp., Phomopsis sp., Cladosporium sp., and Penicillium sp. were also tested and exhibited no interference with the two LAMP primers sets.

Assay sensitivity. A ladder-like pattern in gel electrophoresis (Fig. $3 \mathrm{~A}$ ) or bright green fluorescence with PicoGreen added to the reaction tube under UV (366 nm) light (Figs. 3B and 4) indicated positive results for LAMP (Tomita et al. 2008; Tomlinson et al. 2007). The ITS primer set LITSG1 was more sensitive than the $\beta$-tubulin 2 primer set Ltub2; the amplification limits were 20 and 200 pg per reaction, respectively, when using template DNA extracted from pure cultures. The SDW templates showed no fluorescence in any validation test. As a comparison, PCR primers CaInt2 and ITS4 exhibited the same detection limit as LITSG1.

Sensitivity on greenhouse-grown strawberry leaves. Detection frequency of the LAMP assay was generally higher on leaves that had received more concentrated inoculum, but this trend was not linear.
F2

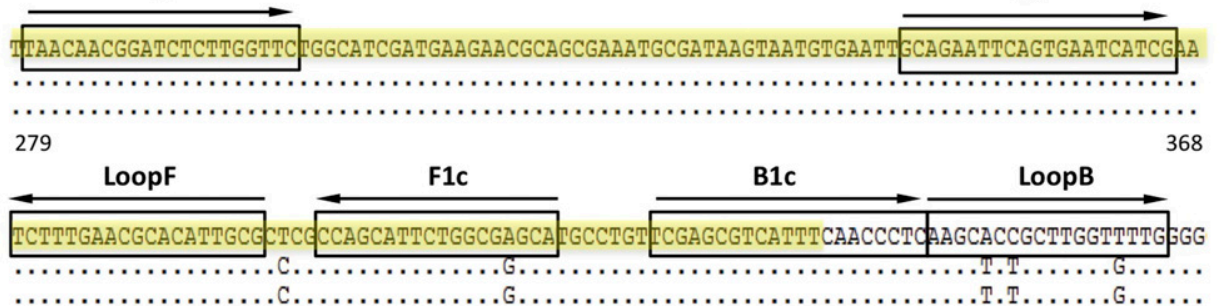

368

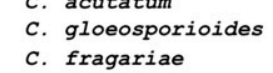

369

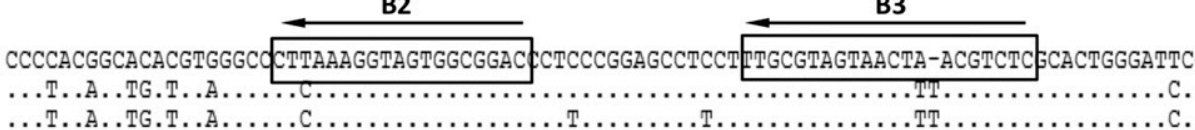

c. gloeosporioides
c. fragariae

C. acutatum

c. gloeosporioides

c. fragariaecc
C. acutatum
C. gloeosporioides
C. fragariae

Fig. 1. Positioning and orientation of loop-mediated isothermal amplification (LAMP) primer set LITSG1, aligned with the nucleotide sequences of the intergenic transcribed spacer (ITS) regions of Colletotrichum acutatum, C. gloeosporioides, and C. fragariae. Outer primers were F3 and B3, internal primers were FIP (F1c+F2) and BIP (B1c+B2), and loop primers were LoopF and LoopB. Only polymorphic nucleotides are shown. A dot (.) indicates an identical nucleotide and a dash (-) indicates a gap in the sequence. Sequence features 5.8S ribosomal RNA (shaded) at 189 to 339 and the internal transcribed spacer 2 at 340 to 456.

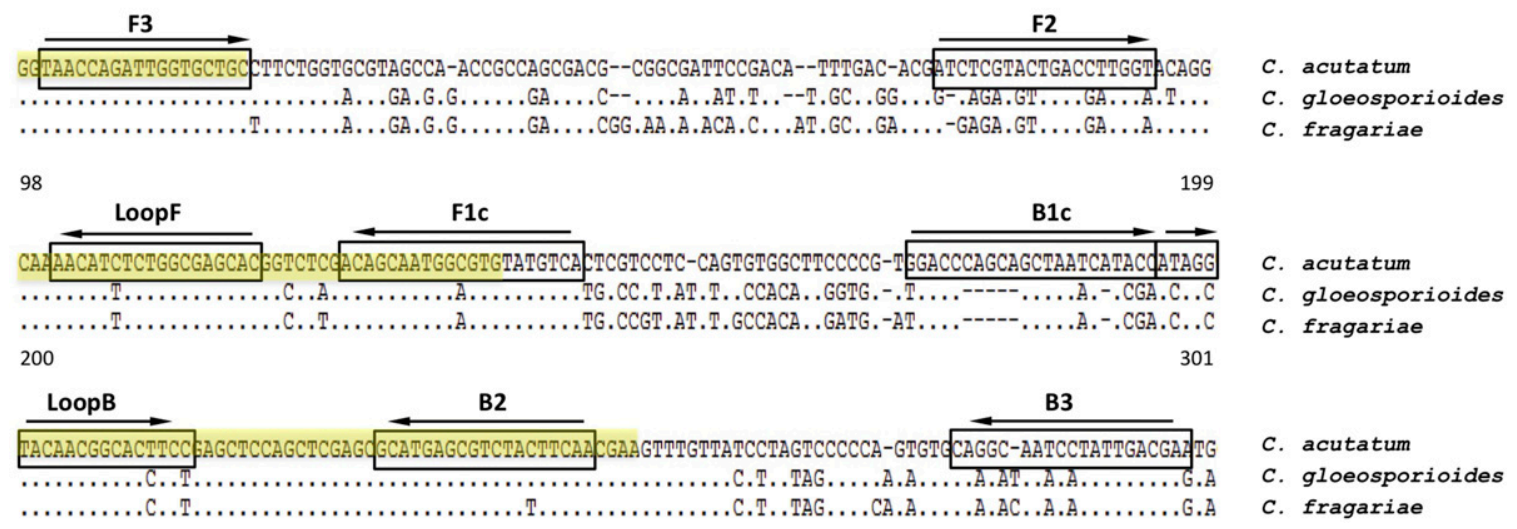

Fig. 2. Positioning and orientation of loop-mediated isothermal amplification primer set Ltub2 aligned with the nucleotide sequence of the $\beta$-tubulin 2 genes of Colletotrichum acutatum, C. gloeosporioides, and C. fragariae. Outer primers were F3 and B3, internal primers were FIP (F1c+F2) and BIP (B1c+B2), and loop primers were LoopF and LoopB. Only polymorphic nucleotides are shown. A dot (.) indicates an identical nucleotide and a dash (-) indicates a gap in the sequence. Sequence features exons at 1 to 27, 98 to 139, and 200 to 253 (shaded) and introns at 28 to 97,140 to 199 , and 254 to 301. 
The most sensitive detection occurred when using LITSG1 primers with the FISA protocol (Table 3). The detection limit for LITSG1 primers on leaves of greenhouse-grown strawberry, expressed as concen-

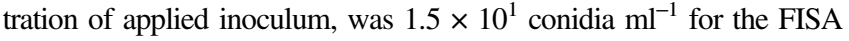
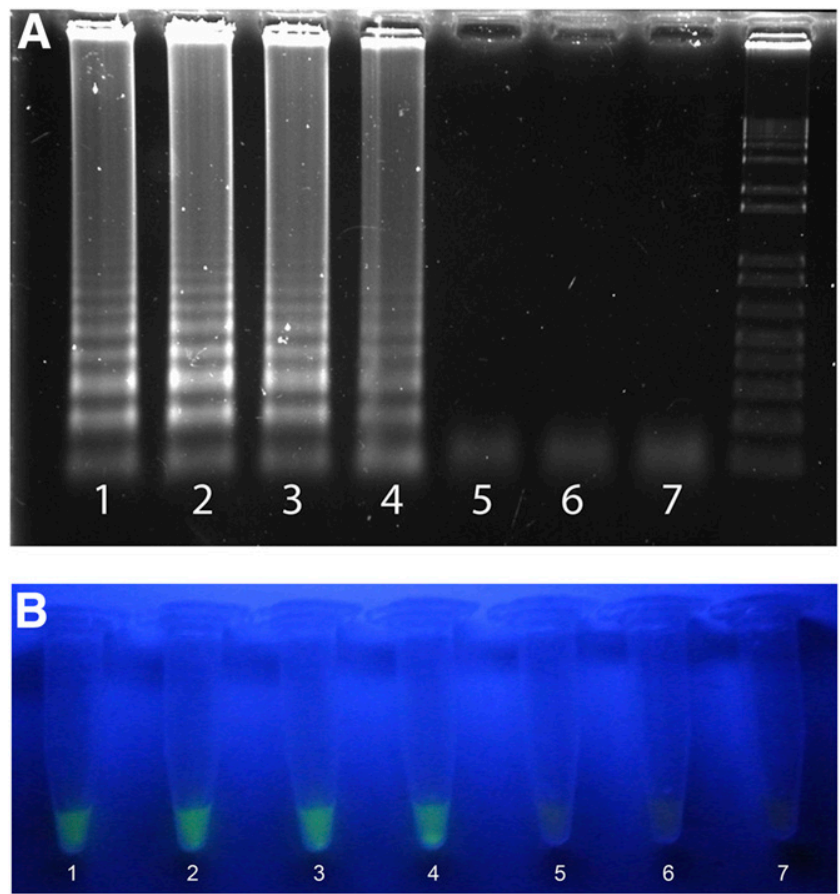

Fig. 3. Sensitivity assay of loop-mediated isothermal amplification (LAMP) primer set LITSG1, following incubation at $65^{\circ} \mathrm{C}$ for $50 \mathrm{~min}$. A serial dilution of Colletotrichum acutatum 07.7 genomic DNA from mycelium was used as template. Lane 1, 20 ng/reaction (rxn); lane 2, $2 \mathrm{ng} / \mathrm{rxn}$; lane 3, $0.2 \mathrm{ng} / \mathrm{rxn}$; lane 4, $20 \mathrm{pg} / \mathrm{rxn}$; lane 5, $2 \mathrm{pg} / \mathrm{rxn}$; lane 6, $0.2 \mathrm{pg} / \mathrm{rxn}$; and lane 7, negative control (water). A, Agarose gel electrophoresis of LAMP reactions. B, PicoGreen fluorescence of LAMP reactions in Eppendorf tubes under 365-nm UV light.

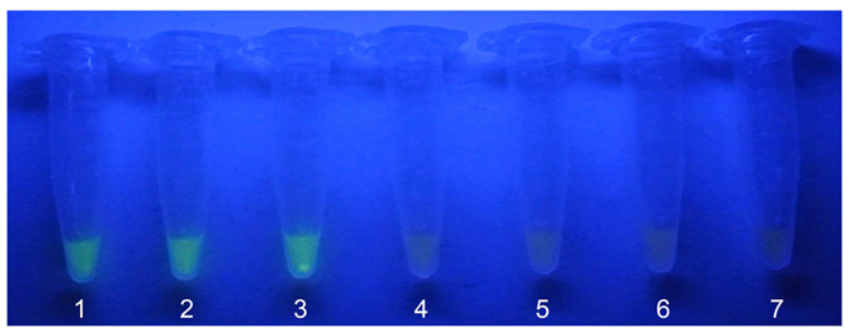

Fig. 4. Sensitivity (based on PicoGreen fluorescence of loop-mediated isothermal amplification [LAMP] reactions under 365-nm UV light) of LAMP primer set Ltub2 at $65^{\circ} \mathrm{C}$ for $50 \mathrm{~min}$. A serial dilution of Colletotrichum acutatum 07.7 genomic DNA was used as template. Lane 1, $20 \mathrm{ng} /$ reaction (rxn); lane 2, 2 ng/rxn; lane 3, 0.2 ng/rxn; lane 4, $20 \mathrm{pg} / \mathrm{rxn}$; lane 5, $2 \mathrm{pg} / \mathrm{rxn}$; lane 6, 0.2 pg/rxn; and lane 7, negative control (water).

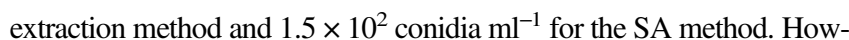
ever, FISA detection success declined to one positive result per three replicates with $1.5 \times 10^{4}$ conidia $\mathrm{ml}^{-1}$. For Ltub2, the detection limit was $1.5 \times 10^{3}$ conidia ml ${ }^{-1}$ for SA and $1.5 \times 10^{2}$ conidia ml ${ }^{-1}$ for FISA.

Primer set LITSG1 consistently detected the pathogen in DNA extracted from a single inoculated leaf $\left(1.5 \times 10^{6}\right.$ conidia ml $\left.{ }^{-1}\right)$ in bulked samples of 50 clean leaves. In contrast, Ltub2 detected the pathogen consistently when the DNA was extracted from a composite sample, included one in 20 or fewer leaves, and, occasionally (one third of assays), one in 50 leaves. PCR using the specific primer pair CaInt2 and ITS4 did not detect the pathogen in any of the composite samples (Table 4).

Detection of $C$. acutatum with LAMP assay in field samples. The LAMP assay using LITSG1 primers detected $C$. acutatum in 34 of 42 leaf samples and all 12 flower samples (Table 5) from the inoculated field in Iowa. Similarly, the LAMP assay using Ltub2 detected 31 of 42 leaf samples and 11 of 12 flower samples. PCR amplification using CaInt 2 and ITS4 primers showed a clearly visible amplification fragment of the correct size (490 bp) for five of 42 leaf samples and eight of 12 flower samples (Table 5). Strawberries with sunken, brown lesions were first scouted in the field on July 31, 2013, 6 days after the leaves were sampled.

In assays of leaves from the inoculated field in Florida, LITSG1 primers detected C. acutatum in all four cultivars. Both DNA extraction methods had similar detection rates, except that, for 'Florida Radiance', FISA was more sensitive than SA. The two resistant cultivars, 'Florida Radiance' and 'Sweet Charlie', had fewer positive reactions compared with the more susceptible cultivars with the SA method; of 15 samples tested per cultivar, positives were obtained for three 'Florida Radiance' and six 'Sweet Charlie' versus 13 'Strawberry Festival' and nine 'Camarosa' samples. Using the FISA method, only 'Sweet Charlie' had a relatively low positive detection rate (6 of 15), whereas other cultivars recorded 10 or more positives among 15 assays (Table 6).

Table 4. Frequency of detection of Colletotrichum acutatum $03.32^{\mathrm{a}}$

\begin{tabular}{|c|c|c|c|c|}
\hline \multirow{2}{*}{$\begin{array}{l}\text { Inoculated } \\
\text { leaves }^{b}\end{array}$} & \multirow{2}{*}{$\begin{array}{c}\text { Noninoculated } \\
\text { leaves }\end{array}$} & \multicolumn{2}{|c|}{ LAMPc $^{c}$} & \multirow{2}{*}{$\frac{\text { PCR }^{c}}{\text { CaInt2/ITS4 }}$} \\
\hline & & LITSG1 & Ltub2 & \\
\hline 0 & 1 & $0^{\mathrm{c}}$ & 0 & 0 \\
\hline 1 & 1 & 3 & 3 & 0 \\
\hline 1 & 10 & 3 & 2 & 0 \\
\hline 1 & 20 & 3 & 3 & 0 \\
\hline 1 & 30 & 3 & 0 & 0 \\
\hline 1 & 40 & 3 & 0 & 0 \\
\hline 1 & 50 & 3 & 1 & 0 \\
\hline
\end{tabular}

${ }^{a}$ Detection by conventional polymerase chain reaction (PCR) with primer set CaInt2/ITS4 and loop-mediated isothermal amplification (LAMP) primer sets LITSG1 and Ltub2 with DNA extracted with the sonicate-agitate method from bulked samples of inoculated and noninoculated greenhousegrown strawberry leaves ('Tristar')

${ }^{\mathrm{b}}$ Number of inoculated leaves combined with noninoculated leaves. Inoculum concentration used to spray leaves was $1.5 \times 10^{6}$ conidia per milliliter.

${ }^{\mathrm{c}}$ Number of positive reactions per three replicate assays.

Table 3. Number of positive leaves ${ }^{\mathrm{a}}$

\begin{tabular}{|c|c|c|c|c|c|c|c|c|}
\hline \multirow[b]{2}{*}{ Concentration $^{b}$} & \multicolumn{4}{|c|}{ SA method } & \multicolumn{4}{|c|}{ FISA method } \\
\hline & LITSG1 & Ltub2 & LITSG1 & $\overline{\text { Ltub2 }}$ & Exp.1 & Exp.2 & Exp.1 & $\overline{\text { Exp.2 }}$ \\
\hline 0 & $0^{\mathrm{b}}$ & 0 & 0 & 0 & 0 & 0 & 0 & 0 \\
\hline $1.5 \times 10^{0}$ & 0 & 0 & 0 & 0 & 0 & 0 & 0 & 0 \\
\hline $1.5 \times 10^{1}$ & 0 & 0 & 0 & 0 & 0 & 1 & 0 & 0 \\
\hline $1.5 \times 10^{2}$ & 1 & 1 & 0 & 0 & 1 & 3 & 1 & 0 \\
\hline $1.5 \times 10^{3}$ & 3 & 1 & 1 & 0 & 1 & 3 & 2 & 2 \\
\hline $1.5 \times 10^{4}$ & 3 & 0 & 1 & 0 & 1 & 1 & 1 & 0 \\
\hline $1.5 \times 10^{5}$ & 3 & 0 & 3 & 0 & 3 & 1 & 2 & 0 \\
\hline $1.5 \times 10^{6}$ & 3 & 1 & 3 & 1 & 3 & 1 & 3 & 1 \\
\hline
\end{tabular}

a Assayed with loop-mediated isothermal amplification primer sets LITSG1 and Ltub2 out of three sampled strawberry trifoliate leaves inoculated with Colletotrichum acutatum strain 03.32 and incubated for 2 days and then either sonicated and agitated (SA method) or frozen, incubated, sonicated, and agitated (FISA method).

$\mathrm{b}$ Concentration of applied inoculum give as the number of conidia per milliliter. After inoculum was sprayed on detached leaves with an electronic atomizer, the leaves were incubated in crispers in darkness for 2 days at $25^{\circ} \mathrm{C}$, before being assayed. 


\section{Discussion}

In this study, we developed and validated the first LAMP assay for detection of the causal agent of strawberry anthracnose. The highly specific Ltub2 LAMP primer set reliably amplified $C$. acutatum but not $C$. gloeosporioides or $C$. fragariae in DNA extracts from pure

Table 5. Number of positive detections of Colletotrichum acutatum ${ }^{\mathrm{a}}$

\begin{tabular}{|c|c|c|c|c|}
\hline \multirow[b]{2}{*}{ Field samples } & \multirow[b]{2}{*}{ No. of samples } & \multicolumn{2}{|c|}{$\begin{array}{l}\text { No. positive by } \\
\text { LAMP } \\
\end{array}$} & \multirow{2}{*}{$\begin{array}{c}\begin{array}{c}\text { No. positive } \\
\text { by PCR }\end{array} \\
\text { CaInt2/ ITS }\end{array}$} \\
\hline & & LITSG1 & Ltub2 & \\
\hline Leaf & 42 & 34 & 31 & 5 \\
\hline Flower & 12 & 12 & 11 & 8 \\
\hline
\end{tabular}

${ }^{a}$ By conventional polymerase chain reaction (PCR) (using primers CaInt2 and ITS4) and loop-mediated isothermal amplification (LAMP) (using primer sets LITSG1 and Ltub2) on DNA extracted with the freeze-incubatesonicate-agitate method from individual strawberry leaves from artificially inoculated field plants ('Tristar') in Iowa.

Table 6. Number of positives out of 15 leaf samples ${ }^{\mathrm{a}}$

\begin{tabular}{|c|c|c|c|c|c|c|c|c|}
\hline \multirow{2}{*}{$\begin{array}{l}\text { LAMP } \\
\text { test results }^{b}\end{array}$} & \multicolumn{2}{|c|}{$\begin{array}{c}\text { 'Florida } \\
\text { Radiance' }\end{array}$} & \multicolumn{2}{|c|}{$\begin{array}{l}\text { 'Sweet } \\
\text { Charlie' }\end{array}$} & \multicolumn{2}{|c|}{$\begin{array}{c}\text { 'Strawberry } \\
\text { Festival' }\end{array}$} & \multicolumn{2}{|c|}{ 'Camarosa' } \\
\hline & SA & $\overline{\text { FISA }}$ & SA & FISA & SA & $\overline{\text { FISA }}$ & SA & FISA \\
\hline Posi & 2 & 11 & 4 & 4 & 5 & 10 & 9 & 8 \\
\hline Weak reaction & 1 & 1 & 2 & 2 & 8 & 1 & 0 & 4 \\
\hline
\end{tabular}

a From artificially inoculated field plants in Florida that were tested for $\mathrm{Col}$ letotrichum acutatum using loop-mediated isothermal amplification (LAMP) primer set LITSG1.

b The plants were inoculated three months before sample collection, and the collected samples were transported in a padded envelope at ambient temperature for 2 days prior to DNA extraction. SA = the sonicate-agitate method and FISA = the freeze-incubate-sonicate-agitate method. cultures. The LITSG1 primer set was less specific, amplifying C. acutatum, C. gloeosporioides, and C. fragariae but had higher sensitivity. Both primer sets detected $C$. acutatum under greenhouse and field conditions. Detection of Colletotrichum species is challenging because of the complex nature of the pathogens; multiple species can cause similar symptoms on one host, and a single species can infect multiple hosts. The broader detection ability of LITSG1 may be advantageous in regions where all three species are present on strawberry, such as in the southeastern U.S. (Smith and Black 1990), but also presents no disadvantage for detection where only C. acutatum is known to occur on strawberry.

LAMP offers potential advantages over other PCR-based methods for screening of nursery transplants or production fields for the anthracnose pathogens during the symptomless phase of colonization, including lower equipment costs, less training required to conduct the assay, and increased convenience. Because it does not need a thermocycler or gel electrophoresis equipment, LAMP can be conducted in nurseries or on farms rather than in a laboratory (Tomlinson et al. 2007, 2010a). Since both primer sets detected $C$. acutatum in the field in the absence of symptoms, they may be valuable tools for detecting these pathogens on nursery transplants, although this potential remains to be tested. We also foresee that our LAMP assay could be modified readily to detect Colletotrichum pathogens on other hosts.

Although clearly defined genetic targets are essential for molecular recognition of pathogens, it is possible that the fluctuating taxonomic status of Colletotrichum pathogens could require a broader range of detection, while still excluding nonpathogenic species (Hyde et al. 2009; Sreenivasaprasad and Talhinhas 2005). Although recent phylogenetic research named 30 species in what had been considered C. acutatum (Baroncelli et al. 2014; Damm et al. 2012; Debode et al. 2015; Talhinhas et al. 2015), we have elected to consider these new taxa as $C$. acutatum sensu lato because, for most of the isolates, there is more than one modern name associated with

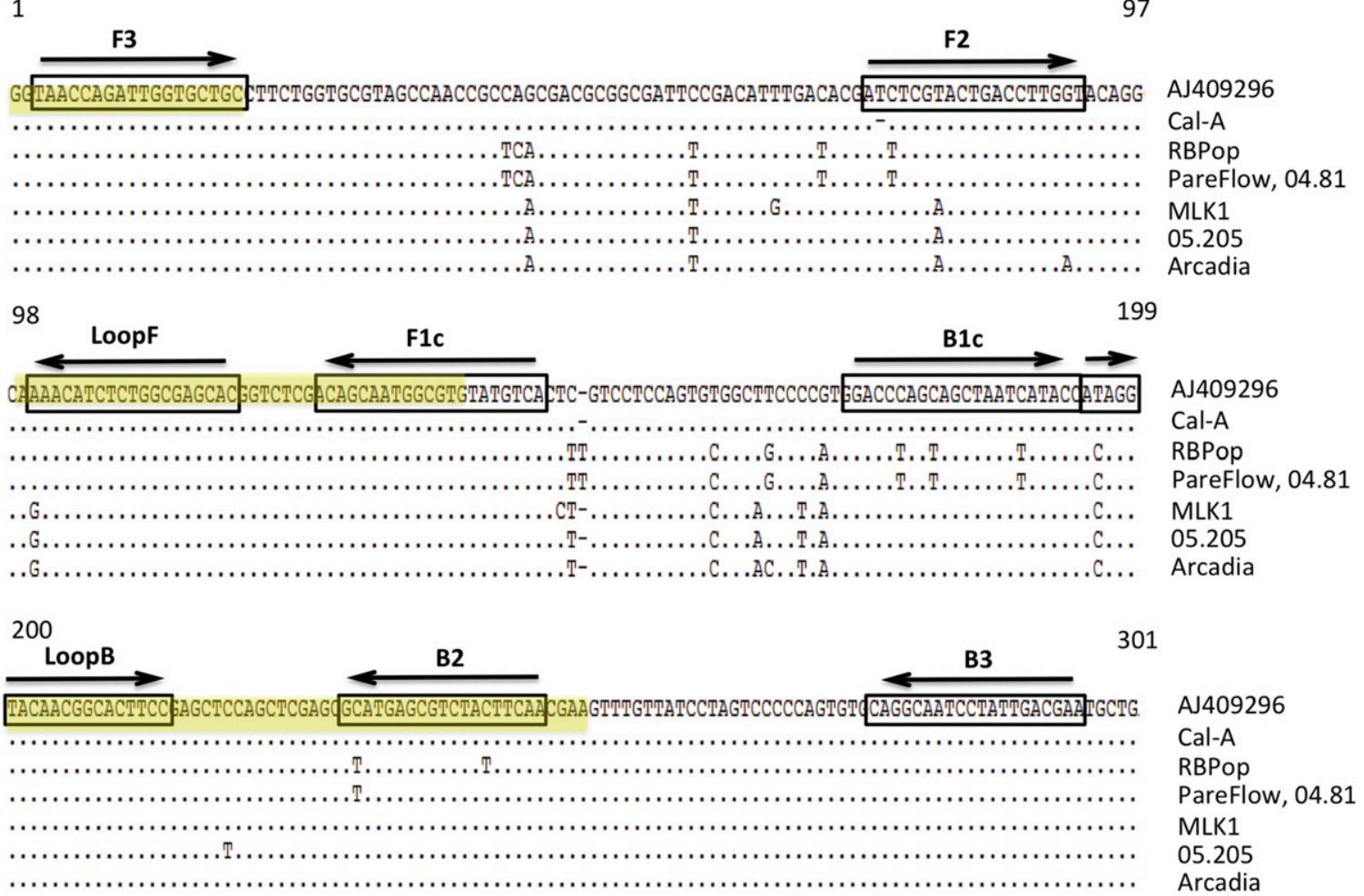

Fig. 5. Positioning and orientation of loop-mediated isothermal amplification primer set Ltub2 aligned with the nucleotide sequence of the $\beta$-tubulin 2 genes of representative isolates of modern species in the Colletotrichum acutatum complex, C. nymphaeae (Cal-A), C. fioriniae (RBPop, PareFlow and 04.81), C. limetticola (MLK1), C. tamarilli (05.205), C. costaricense (Arcadia), and the AJ409296 sequence that was used for primer design. Outer primers were F3 and B3, internal primers were FIP (F1c+F2) and BIP (B1C+B2), and loop primers were LoopF and LoopB. Only polymorphic nucleotides are shown. A dot (.) indicates an identical nucleotide and a dash (-) indicates a gap in the sequence. Sequence features exons at 1 to 27,98 to 139, and 200 to 253(shaded) and introns at 28 to 97,140 to 199 , and 254 to 301. 
the two target genes ITS and $\beta$-tubulin 2 (Table 1). Nevertheless, the findings of Damm et al. (2012) aided us in understanding the genetic background of the pathogen complex and in selecting candidate genes for LAMP primer development and further improvement, and the new species under the $C$. acutatum complex that were detected by the LAMP assay were also listed (Table 1). For some species, the two detected genes gave different species names; Damm et al. (2012) indicated that $\beta$-tubulin 2 gene sequence can better identify the recently described species.

The choice of target gene directly affected the sensitivity and specificity of detection. The ITS gene is the most widely used target gene for DNA-based detection of fungi (Atkins and Clark 2004). As a multicopy gene, it also provides better detection sensitivity than singlecopy genes (Debode et al. 2009). LAMP detection methods have been reported to have very high specificity (Notomi et al. 2000, Tomita et al. 2008). In the LAMP assay for C. acutatum, however, the $5.8 \mathrm{~s}$ and ITS2 regions were not sufficiently variable to separate C. acutatum from the other two Colletotrichum pathogens of strawberry, even though there were seven differences in base pairs of the three LAMP primers, one in F1, three in the LoopB primer, one in B2, and two in the B3 primer (Fig. 1). None of the differences were at the $3^{\prime}$ end of the primers. In contrast, the $\beta$-tubulin 2 gene of $C$. acutatum had more variability, including some gaps; as a result, primers from this region were more species-specific (Fig. 2). Among C. acutatum isolates recovered from a range of hosts, there were from one to seven differences in base pairs in the target $\beta$-tubulin gene, but only isolates from Key lime and orange did not produce stable amplification. For example, the isolate Arcadia (C. costaricense) had two base-pair differences in F2 and one base-pair difference in the LoopB primer (Table 1; Fig. 5). Since loop primers function mainly to accelerate the speed of the amplification but are not critical to specificity, a difference at the $3^{\prime}$ end of the F2 primer apparently accounted for the unstable amplifications. These results indicate that, when designing LAMP primers for a species or subgroup, it is advisable to avoid polymorphisms at the $3^{\prime}$ end of primers.

To minimize the risk of contamination during transfers of LAMP amplification products in no-template controls that could lead to false positives (Tomita et al. 2008), in-tube detection with PicoGreen reagent instead of agarose gel electrophoresis was used in most of our LAMP assays. PicoGreen reagent can bind to DNA and fluoresce under UV light; it was added to each tube after amplification in a separate room from the reagent and sample preparation room. LAMP has a higher contamination risk than PCR because of its high amplification efficiency (Tomita et al. 2008). In this research, contamination resulted primarily from the LAMP product after amplification and was difficult to remove. Even compared with gel electrophoresis, in-tube detection had a much lower contamination risk, although contamination may still come from using the same set of pipettes or tube racks before and after LAMP detection and using PCR strips with strip caps. In order to minimize the risk of contamination, a different set of pipettes, tube racks, and separate rooms should be used for the reagent and sample preparation than for PicoGreen addition and observation of color development. If strawberry nurseries or farms use this detection method in the future, devices that detect LAMP results without opening the testing tubes are highly recommended (Kaczmarek et al. 2014; Keremane et al. 2015). Additional experimentation on sampling strategies, on-site DNA extraction methods, and optimization of assay sensitivity are needed before the LAMP assay can be recommended for nonlaboratory applications.

In the LAMP sensitivity assay with greenhouse-grown strawberry leaves, we noticed differences between two runs that may be caused by the differences in the level of pathogen infection and secondary spore production within the 2 days of incubation. Detection results were not linearly related to the initial inoculum at concentrations less than $1.5 \times 10^{6}$ conidia per milliliter. These differences occurred primarily when using the SA method with both primer sets and the FISA method using Ltub2. In general, we found that the FISA method combined with the LITSG1 primer set was more robust for detection at initial inoculum concentrations less than $1.5 \times 10^{6}$ conidia per milliliter, using single leaves in which it was able to detect at least one inoculated leaf out of three at $1.5 \times 10^{2}$ conidia per milliliter. Pérez-Hernández et al. (2008) also showed that extracts using the FISA method were more sensitive than SA extracts in conjunction with a nested PCR method for detection of $C$. acutatum on symptomless strawberry leaves. In assays using the SA extraction method to detect pathogen initial inoculum, at $1.5 \times 10^{6}$ conidia per milliliter, bulked with clean leaves, the LITSG1 primer set had higher sensitivity and was more robust than Ltub2, suggesting that LITSG1 could be used in an initial screening assay for the presence of Colletotrichum spp. on bulked samples of strawberry plants. Based on our results, the LITSG1 primer set with the FISA DNA extraction method has high potential to be used for on-site detection of $C$. acutatum via LAMP assays.

In detecting $C$. acutatum in an Iowa strawberry field, the LAMP assay exhibited higher sensitivity and consistency than conventional PCR. Interestingly, inoculated strawberry flowers from this field were detected more readily than inoculated leaves by both LAMP and PCR. It is possible that population levels on flowers were higher than on leaves because flower parts were more conducive to growth of the pathogen. Leandro et al. (2003) found that flower extracts stimulate conidia production by $C$. acutatum to a greater extent than leaf extracts.

Samples from the Florida field may have represented natural infection conditions more realistically than the Iowa field due to secondary dissemination during the 3-month time lag between inoculation and sampling. Interestingly, resistant cultivars had lower levels of detection on leaves, suggesting that the pathogen sporulated less on resistant cultivars than on susceptible cultivars.

This series of experiments from a laboratory, a greenhouse, and two field locations provides evidence for the potential value of LAMP as an on-site detection method. However, performance of the LAMP assay for presymptom detection of the pathogen should be further evaluated in a naturally inoculated field with more heterogeneous spatial distribution of infected leaves, and an optimal sampling method should be developed. Although its detection limit is higher than that of realtime PCR or nested PCR (Debode et al. 2009; Pérez-Hernández et al. 2008), the LAMP assay has a significant practical advantage over these technologies because it can be adapted to plant-screening efforts on-site or outside of a conventional laboratory setting, making it more accessible to strawberry growers and their pest management advisors.

\section{Acknowledgments}

We acknowledge financial support from the Specialty Crop Research Initiative (SCRI) program of the United States Department of Agriculture National Institute of Food and Agriculture Project 2010-51181-21113. We also thank the China Scholarship Council for providing a Ph.D. scholarship to the first author. We are grateful to F. Louws (North Carolina State University), B. Smith (Mississippi State University) and G. Schnabel (Clemson University) for providing isolates used in this study.

\section{Literature Cited}

Atkins, S. D., and Clark, I. M. 2004. Fungal molecular diagnostics: A mini review. J. Appl. Genet. 45:3-15

Baroncelli, R., Sreenivasaprasad, S., Sukno, S. A., Thon, M. R., and Holub, E. 2014. Draft genome sequence of Colletotrichum acutatum sensu lato (Colletotrichum fioriniae). Genome Announc. 2:e00112-14.

Cannon, P. F., Damm, U., Johnston, P. R., and Weir, B. S. 2012. Colletotrichum - Current status and future directions. Stud. Mycol. 73:181-213.

Damm, U., Cannon, P., Woudenberg, J., and Crous, P. 2012. The Colletotrichum acutatum species complex. Stud. Mycol. 73:37-113.

Debode, J., Van Hemelrijck, W., Baeyen, S., Creemers, P., Heungens, K., and Maes, M. 2009. Quantitative detection and monitoring of Colletotrichum acutatum in strawberry leaves using real-time PCR. Plant Pathol. 58: 504-514.

Debode, J., Van Hemelrijck, W., Xu, X. M., Maes, M., Creemers, P., and Heungens, K. 2015. Latent entry and spread of Colletotrichum acutatum (species complex) in strawberry fields. Plant Pathol. 64:385-395.

Denoyes-Rothan, B., Guérin, G., Délye, C., Smith, B., Minz, D., Maymon, M., and Freeman, S. 2003. Genetic diversity and pathogenic variability among isolates of Colletotrichum species from strawberry. Phytopathology 93:219-228.

Freeman, S., Horowitz, S., and Sharon, A. 2001b. Pathogenic and nonpathogenic lifestyles in Colletotrichum acutatum from strawberry and other plants. Phytopathology 91:986-992.

Freeman, S., Minz, D., Maymon, M., and Zveibil, A. 2001a. Genetic diversity within Colletotrichum acutatum sensu Simmonds. Phytopathology 91:586592. 
Gardes, M., and Bruns, T. D. 1993. ITS primers with enhanced specificity for basidiomycetes, application to the identification of mycorrhizae and rusts. Mol. Ecol. 2:113-118.

Guerber, J. C., Liu, B., Correll, J. C., and Johnston, P. R. 2003. Characterization of diversity in Colletotrichum acutatum sensu lato by sequence analysis of two gene introns, mtDNA and intron RFLPs, and mating compatibility. Mycologia 95:872-895.

Howard, C. M., Maas, J. L., Chandler, C. K., and Afbregts, E. E. 1992. Anthracnose of strawberry caused by the Colletotrichum complex in Florida. Plant Dis. 76:976-981.

Hyde, K., Cai, L., Cannon, P. F., Crouch, J. A., Crous, P. W., Damm, U., Goodwin, P. H., Chen, H., Johnston, P. R., Jones, E. B. G., Liu, Z. Y., McKenzie, E. H. C., Moriwaki, J., Noireung, P., Pennycook, S. R., Pfenning, L. H., Prihastuti, H., Sato, T., Shivas, R. G., Tan, Y. P., Taylor, P. W. J., Weir, B. S., Yang, Y. L., and Zhang, J. Z. 2009. Colletotrichum-Names in current use. Fungal Divers. 39:147-182.

Kaczmarek, J., Irzykowski, W., Burzyński, A., and Jęryczka, M. 2014. The detection of Plasmodiophora brassicae using loop-mediated isothermal DNA amplification. Acta Agrobotanica 67:59-66.

Keremane, M. L., Ramadugu, C., Rodriguez, E., Kubota, R., Shibata, S., Hall, D. G., Roose, M. L., Jenkins, D., and Lee, R. F. 2015. A rapid field detection system for citrus huanglongbing associated 'Candidatus Liberibacter asiaticus' from the psyllid vector, Diaphorina citri Kuwayama and its implications in disease management. Crop Prot. 68:41-48.

Kubota, R., Vine, B. G., Alvarez, A. M., and Jenkins, D. M. 2008. Detection of Ralstonia solanacearum by loop-mediated isothermal amplification. Phytopathology 98:1045-1051.

Leandro, L. F. 2002. Ecology and epidemiology of Colletotrichum acutatum on symptomless strawberry leaves. Retrospective Theses and Dissertations. Paper 527. http://lib.dr.iastate.edu/rtd/527. Iowa State University, Ames, IA.

Leandro, L. F., Gleason, M. L., Nutter, F. W., Wegulo, S. N., and Dixon, P. M. 2001. Germination and sporulation of Colletotrichum acutatum on symptomless strawberry leaves. Phytopathology 91:659-664.

Leandro, L. F. S., Gleason, M. L., Nutter, F. W., Wegulo, S. N., and Dixon, P. M. 2003. Strawberry plant extracts stimulate secondary conidiation by Colletotrichum acutatum on symptomless leaves. Phytopathology 93:1285-1291.

MacKenzie, S. J., Peres, N. A., Barquero, M. P., Arauz, L. F., and Timmer, L. W. 2009. Host range and genetic relatedness of Colletotrichum acutatum isolates from fruit crops and leatherleaf fern in Florida. Phytopathology 99:620-631.

Martinez-Culebras, P. V., Querol, A., Suarez-Fernandez, M. B., Garcia-Lopez, M. D., and Barrio, E. 2003. Phylogenetic relationships among Colletotrichum pathogens of strawberry and design of PCR primers for their identification. J. Phytopathol. 151:135-143.

Mori, Y., Nagamine, K., Tomita, N., and Notomi, T. 2001. Detection of loopmediated isothermal amplification reaction by turbidity derived from magnesium pyrophosphate formation. Biochem. Biophys. Res. Commun. 289:150-154.

Nagamine, K., Hase, T., and Notomi, T. 2002. Accelerated reaction by loopmediated isothermal amplification using loop primers. Mol. Cell. Probes 16: 223-229.

Niessen, L., and Vogel, R. F. 2010. Detection of Fusarium graminearum DNA using a loop-mediated isothermal amplification (LAMP) assay. Int. J. Food Microbiol. 140:183-191.
Notomi, T., Okayama, H., Masubuchi, H., Yonekawa, T., Watanabe, K., Amino, N., and Hase, T. 2000. Loop-mediated isothermal amplification of DNA. Nucleic Acids Res. 28:e63.

Parikka, P., and Lemmetty, A. 2004. Tracing latent infection of Colletotrichum acutatum on strawberry by PCR. Eur. J. Plant Pathol. 110:393-398.

Pavan, W., Fraisse, C. W., and Peres, N. A. 2011. Development of a web-based disease forecasting system for strawberries. Comput. Electron. Agric. 75:169-175.

Peres, N. A., Timmer, L. W., Adaskaveg, J. E., and Correll, J. C. 2005. Lifestyles of Colletotrichum acutatum. Plant Dis. 89:784-796.

Pérez-Hernández, O., Nam, M. H., Gleason, M. L., and Kim, H. G. 2008. Development of a nested polymerase chain reaction assay for detection of Colletotrichum acutatum on symptomless strawberry leaves. Plant Dis. 92:1655-1661.

Smith, B. J. 2008. Epidemiology and pathology of strawberry anthracnose: A North American perspective. HortScience 43:69-73.

Smith, B. J., and Black, L. L. 1990. Morphological, cultural, and pathogenic variation among Colletotrichum species isolated from strawberry. Plant Dis. 74:69-76.

Sreenivasaprasad, S., Sharada, K., Bronw, E., and Mills, P. R. 1996. PCR-based detection of Colletotrichum acutatum on strawberry. Plant Pathol. 45:650-655.

Sreenivasaprasad, S., and Talhinhas, P. 2005. Genotypic and phenotypic diversity in Colletotrichum acutatum, a cosmopolitan pathogen causing anthracnose on a wide range of hosts. Mol. Plant Pathol. 6:361-378.

Talhinhas, P., Gonçalves, E., Sreenivasaprasad, S., and Oliveira, H. 2015 Virulence diversity of anthracnose pathogens (Colletotrichum acutatum and $C$. gloeosporioides species complexes) on eight olive cultivars commonly grown in Portugal. Eur. J. Plant Pathol. 142:73-83.

Talhinhas, P., Sreenivasaprasad, S., Neves-Martins, J., and Oliveira, H. 2002. Genetic and morphological characterization of Colletotrichum acutatum causing anthracnose of lupins. Phytopathology 92:986-996.

Tomita, N., Mori, Y., Kanda, H., and Notomi, T. 2008. Loop-mediated isothermal amplification (LAMP) of gene sequences and simple visual detection of products. Nat. Protoc. 3:877-882.

Tomlinson, J. A., Barker, I., and Boonham, N. 2007. Faster, simpler, more-specific methods for improved molecular detection of Phytophthora ramorum in the field. Appl. Environ. Microbiol. 73:4040-4047.

Tomlinson, J. A., Dickinson, M. J., and Boonham, N. 2010a. Rapid detection of Phytophthora ramorum and P. kernoviae by two-minute DNA extraction followed by isothermal amplification and amplicon detection by generic lateral flow device. Phytopathology 100:143-149.

Tomlinson, J. A., Dickinson, M. J., and Boonham, N. 2010b. Detection of Botrytis cinerea by loop-mediated isothermal amplification. Lett. Appl. Microbiol. 51: 650-657.

Van Hemelrijck, W., Debode, J., Heungens, K., Maes, M., and Creemers, P. 2010 Phenotypic and genetic characterization of Colletotrichum isolates from Belgian strawberry fields. Plant Pathol. 59:853-861.

White, T. J., Bruns, S., Lee, S., and Taylor, J. 1990. Amplification and direct sequencing of fungal ribosomal RNA genes for phylogenetics. Pages 315-322 in: PCR Protocols: A Guide to Methods and Applications. Academic Press, San Diego, CA.

Xie, L., Zhang, J., Wan, Y., and Hu, D. 2010. Identification of Colletotrichum spp. isolated from strawberry in Zhejiang Province and Shanghai City, China. J. Zhejiang Univ. Sci. B 11:61-70. 